\title{
Free Children's Visits and General Practice Attendance
}

Michael Edmund O'Callaghan, MICGP, MSc

Lina Zgaga, $M D, M S c, P b D$

Darach O'Ciardba, MICGP

Thomas O'Dowd, MA, MD, MICGP, FRCGP, FTCD

Department of Public Health and Primary Care, Trinity College Dublin, Dublin, Ireland
Conflicts of interest: authors report none.

\section{CORRESPONDING AUTHOR}

Michael O'Callaghan, MICGP, MSc Department of Public Health and Primary Care

6th Fl, The Russell Centre

Tallaght Cross West, Dublin 24, Ireland drmichaelocallaghan@gmail.com

\begin{abstract}
PURPOSE In July 2015, all children aged younger than 6 years gained free access to daytime and out-of-hours general practice services in the Republic of Ireland. Although 30\% previously had free access, 70\% did not.
\end{abstract}

METHODS To examine subsequent changes in service use, we retrospectively analyzed anonymized visitation data from 8 general practices in North Dublin providing daytime service and their local out-of-hours service, comparing the 1 year before and the 1 year after introduction of free care.

RESULTS In the year after granting of free general practice care for children younger than 6 years, 9.4\% more children attended the daytime services and $20.1 \%$ more children were seen in the out-of-hours services. Annual number of visits by patients increased by $28.7 \%$ for daytime services and by $25.7 \%$ for outof-hours services, translating to 6,682 more visits overall. Average visitation rate for children this age increased from 2.77 visits per year to 3.25 visits per year for daytime services, but changed little for out-of-hours services, from 1.52 visits per year to 1.59 visits per year.

CONCLUSIONS Offering free childhood general practice services led to a dramatic increase in visits. This increase has implications for future health care service planning in mixed public and privately funded systems.

Ann Fam Med 2018;16:246-249. https://doi.org/10.1370/afm.2229.

\section{INTRODUCTION}

$\mathrm{V}$ isitation rates are influenced by the way health care is financed ${ }^{1,2}$ In the Republic of Ireland, 55\% of all citizens do not qualify for state-funded, means-tested general practitioner care ${ }^{3}$ and thus must pay out-of-pocket fees (approximately US $\$ 50$ to US $\$ 65$ ) for each general practice visit. ${ }^{4}$

On July 1, 2015, all 440,000 children aged younger than 6 years in the Republic of Ireland were granted free access to general practice visits, regardless of parental income. ${ }^{5,6}$ This policy change allowed 300,000 additional children free visits to both daytime and out-of-hours care settings. ${ }^{6}$

The primary aim of this study was to use general practice electronic health records to analyze changes in daytime and out-of-hours service use since implementation of the new policy.

\section{METHODS}

We used anonymized retrospective visit data from general practice electronic health record systems. Ethical approval for the study was obtained from the Trinity College Dublin/Health Service Executive General Practice Training Scheme Ethics Committee.

\section{Settings}

We studied health care use in 2 settings: 8 daytime general practice services and their local out-of-hours service, called NorthDoc. NorthDoc offers urgent general practice services outside of normal office hours from 5 treatment centers in North County Dublin. It covers 140 participat- 
ing general practices, including the 8 in this study. ${ }^{7}$ Data pertaining to face-to-face general practice visits were collected for a 1-year period before the date of introduction of free general practice care (July 1, 2014 to June 30,2015$)$ and for a 1 -year period after that change (July 1, 2015 to June 30, 2016).

\section{Data Collection}

For daytime services, we sent all 140 practices registered with NorthDoc an e-mail inviting them to participate if they used the electronic health record Socrates. Eight practices indicated their interest and thus were included in this study.

For out-of-hours service, we collected anonymized visitation data for the study period from NorthDoc's central database. All 140 general practices are included in this data set.

\section{Analyses}

We analyzed differences in the number of patients making visits, for both those paying out of pocket and those seen free of charge, and their number of visits in the period before and period after the policy change using the $\chi^{2}$ test.

\section{RESULTS}

Table 1 shows general practice visitation data for both the daytime and out-of-hours settings. Comparison of the periods before and after the policy change showed significant increases in both numbers of patients and numbers of visits by children aged younger than 6 years, in daytime and out-of-hours settings alike $(P<.001$ for all). Figure 1 shows changes over time in number of visits per month for this age-group.

\section{Daytime Services}

The number of children aged younger than 6 years who used the daytime general practice services at least once increased from 3,540 in the period before the policy change to 3,874 in the period thereafter (a $9.4 \%$ increase). General practitioners saw children this age for 9,789 visits in the former period and for 12,600 visits in the latter period (a $28.7 \%$ increase).

The average visitation rate for all children aged younger than 6 years rose from 2.77 (95\% CI, 2.68$2.85)$ visits per patient per year in the period before policy change to 3.25 (95\% CI, 3.17-3.33) visits per patient per year in the period after policy change. The number of children having free visits almost tripled to 3,347 during the latter period.

\section{Out-of-Hours Services}

A total of 9,898 children aged $<6$ years made 15,087 visits to the general practice out-of-hours service in the period before the policy change, and 11,890 children made 18,958 visits in the period after. The difference equated to $20.1 \%$ more children seen at least once and $25.7 \%$ more visits in the latter period.

The number of children seen free of charge more than doubled to 10,824 during the year after policy change. These children made a total of 17,290 visits. The average visitation rate for all children aged younger than 6 years changed little, from 1.52 visits per patient per year to 1.59 visits per patient per year comparing periods before and after the policy change.

\section{DISCUSSION}

Introduction of free general practice care for all children aged younger than 6 years led to a significant, if

Table 1. Comparison of General Practice Use in the Year Before and the Year After Policy Change

\begin{tabular}{|c|c|c|c|c|c|c|c|c|c|c|}
\hline \multirow{3}{*}{$\begin{array}{l}\text { Setting and } \\
\text { Payment } \\
\text { Status }\end{array}$} & \multicolumn{5}{|c|}{ Year Before Policy Change } & \multicolumn{5}{|c|}{ Year After Policy Change } \\
\hline & \multicolumn{2}{|c|}{ All Ages } & \multicolumn{3}{|c|}{ Aged $<6 y$} & \multicolumn{2}{|c|}{ All Ages } & \multicolumn{3}{|c|}{ Aged $<6 y$} \\
\hline & Patients & Visits & Patients & Visits & $\begin{array}{c}\text { Visits per } \\
\text { Patient }\end{array}$ & Patients & Visits & Patients & Visits & $\begin{array}{c}\text { Visits per } \\
\text { Patient } \\
\end{array}$ \\
\hline \multicolumn{11}{|l|}{ Daytime } \\
\hline Out of pocket & 15,828 & 39,457 & 2,415 & 6,053 & 2.51 & 15,842 & 39,419 & $1,011^{\mathrm{a}}$ & $1,753^{\mathrm{a}}$ & 1.73 \\
\hline Free of charge & 13,991 & 60,847 & 1,142 & 3,736 & 3.27 & 15,148 & 67,187 & $3,347^{\mathrm{a}}$ & $10,847^{a}$ & 3.24 \\
\hline Total ${ }^{b}$ & 29,951 & 100,304 & 3,540 & 9,789 & 2.77 & 31,143 & 106,606 & 3,874 & 12,600 & 3.25 \\
\hline \multicolumn{11}{|l|}{ Out of hours } \\
\hline Out of pocket & 14,782 & 17,365 & 5,023 & 6,565 & 1.31 & 12,307 & 13,603 & $1,456^{\mathrm{a}}$ & $1,619^{a}$ & 1.11 \\
\hline Free of charge & 21,558 & 31,673 & 5,017 & 8,484 & 1.69 & 27,569 & 40,704 & $10,824^{a}$ & $17,290^{a}$ & 1.60 \\
\hline Unknown & 299 & 308 & 34 & 38 & 1.12 & 339 & 365 & 41 & 49 & 1.20 \\
\hline Total ${ }^{b}$ & 36,300 & 49,346 & 9,898 & 15,087 & 1.52 & 39,613 & 54,672 & 11,890 & 18,958 & 1.59 \\
\hline
\end{tabular}




\section{Figure 1. Temporal pattern of monthly general practice visits by children aged younger than 6 years.}

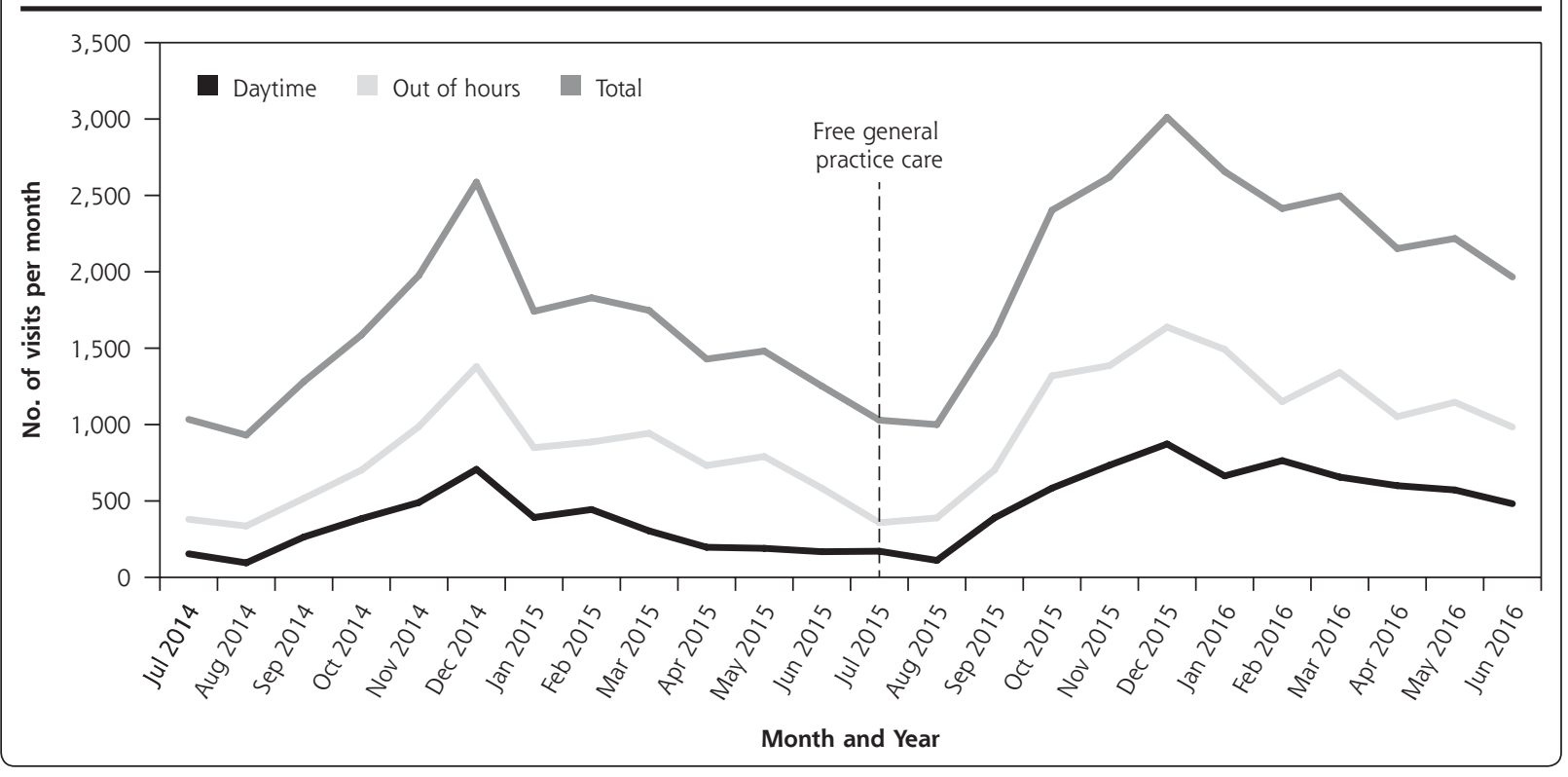

predictable, rise in the number of children seen free of charge and a sharp fall in the number paying out of pocket. The out-of-pocket number did not drop to zero, however, as some parents used general practice services before completing the application process for free visits. Overall, 9\% and 20\% more children attended the daytime and out-of-hours services, respectively, at least once in the year after the policy change.

Number of visits by children aged younger than 6 years increased in both settings by more than $25 \%$. After the granting of free care, the overall visitation rates for children younger than 6 years approached that of those seen free of charge before the policy change. Although both the daytime and out-of-hours services saw more patients of all ages in the period after the policy change, children aged younger than 6 years accounted for a disproportionate increase in service use: $45 \%$ and $73 \%$ of the additional visits in the year after the policy change to the daytime and the out-of-hours services, respectively, were by children this age.

The birth rate dropped by $3 \%$ over the study period $^{8}$ and numbers of general practitioners employed in each setting were similar throughout the study. In addition, although seasonal variation was seen as usual (Figure 1), there were no notable disease outbreaks in North Dublin during the study period that otherwise might explain increased service use. Further research is needed to establish whether severity of medical issues changed when access was free and whether increased workload had effects on general practitioners and patients.
Demand for general practice services is increasing worldwide, both in daytime settings $\mathrm{s}^{9,10}$ and out-ofhours settings. ${ }^{11,12}$ Equitable access should be a cornerstone of any health care system, but making services available free of charge inevitably increases service use. In the Republic of Ireland, there are already indications that the general practitioner workforce may struggle to meet demand in the near future, ${ }^{13,14}$ so future plans to extend state-funded general practice care to all groups ${ }^{15}$ will require careful workforce planning.

To read or post commentaries in response to this article, see it online at http://www. AnnFamMed.org/content/16/3/246.

Key words: general practice; health care utilization; primary health care; after-hours; out-of-hours; child; pediatrics; Ireland; fee-for-service; fees and charges; practice-based research; health planning; state medicine

Submitted June 26, 2017; submitted, revised, September 22, 2017; accepted November 22, 2017.

Acknowledgments: The authors wish to thank the general practitioners and the out-of-hours cooperative NorthDoc for facilitating analysis of their anonymized visitation data.

\section{References}

1. van Doorslaer E, Masseria C, OECD Health Equity Research Group. OECD Health working paper No. 14: income-related inequality in the use of medical care in 21 OECD countries. https://www.oecd. org/els/health-systems/31743034.pdf. Published May 11, 2004. Accessed Jun 6, 2017.

2. Detollenaere J, Hanssens L, Vyncke V, De Maeseneer J, Willems S. Do we reap what we sow? Exploring the association between the strength of European primary healthcare systems and inequity in unmet need. PLOS ONE. 2017;12(1):e0169274. 
3. Department of Health (DOH). Health in Ireland, key trends 2016. Section 4: primary care and community services. http://health.gov. ie/wp-content/uploads/2016/12/Health-in-Ireland-Key-Trends-2016. pdf. Published 2016. Accessed Jun 12, 2017.

4. The Competition Authority. Competition in professional services; general medical practitioners. Part 1: overview of the GP profession. https://www.ccpc.ie/business/research/market-studies/reportgeneral-medical-practitioners/. Published Dec 2010. Accessed Jun 12, 2017.

5. Health Service Executive (HSE). HSE Web site. Under 6s GP visit card. https://www.hse.ie/eng/cards-schemes/gp-visit-cards/under-6sgp-visit-card/. Published 2015. Accessed Jun 12, 2017.

6. Health Service Executive (HSE), National Doctor Training and Planning, HR Directorate, Health Service Executive, Dr Steevens' Hospital, Dublin 8, Ireland. Medical workforce planning: future demand for general practitioners 2015-2025. https://www.hse.ie/eng/staff/ leadership-education-development/met/plan/gp-medical-workforceplanning-report-sept-2015.pdf. Published Sep 2015. Accessed Jun 12, 2017.

7. NorthDoc Medical Services Limited. NorthDoc Medical Services web site. Is my GP a member of NorthDoc? http://www.northdoc.ie/ is-my-gp-a-member-of-northdoc/. Accessed Jun 6, 2017.

8. Central Statistics Office (CSO). CSO web site. Number of births, deaths and marriages. http://www.cso.ie/multiquicktables/ quickTables.aspx?id=vsa02_vsa09_vsa18. Accessed Jun 6, 2017.

9. Baird B, Charles A, Honeyman M, Maguire D, Das P. The Kings Fund web site. Understanding pressures in general practice. https:// www.kingsfund.org.uk/publications/pressures-in-general-practice. Published May 2016. Accessed Jun 6, 2017.
10. Petterson SM, Liaw WR, Tran C, Bazemore AW. Estimating the residency expansion required to avoid projected primary care physician shortages by 2035. Ann Fam Med. 2015;13(2):107-114.

11. Salisbury C. The demand for out-of-hours care from GPs: a review. Fam Pract. 2000;17(4):340-347.

12. Huibers LA, Moth G, Bondevik GT, Kersnik J, Huber CA, Christensen $M B$, et al. Diagnostic scope in out-of-hours primary care services in eight European countries: an observational study. BMC Fam Pract. 2011;12:30.

13. Teljeur C, Thomas S, O'Kelly FD, O'Dowd T. General practitioner workforce planning: assessment of four policy directions. BMC Health Serv Res. 2010;10:148.

14. Collins C, Mansfield G, O'Ciardha D, Ryan K; Irish College of General Practitioners (ICGP). Planning for the future Irish general practitioner workforce- informed by a national survey of GP trainees and recent GP graduates. http://www.lenus.ie/hse/ bitstream/10147/617140/1/Planning_for_the_Future_Irish_General_ Practitioner_Workforce.pdf. Accessed Jun 6, 2017.

15. Department of Health (DOH). Future health. A strategic framework for reform of the health service 2012-2015. http://health.gov.ie/ wp-content/uploads/2014/03/Future_Health.pdf. Published Nov 2012. Accessed Jun 6, 2017.

\section{CHANGE-OF-ADDRESS FORM \\ FAMILY MEDICINE}

Please complete this form and mail to the following address or fax to Annals Circulation at 913-906-6080:

Annals of Family Medicine, Circulation Department, 11400 Tomahawk Creek Pkwy, Leawood, KS 66211-2680
Check if member of sponsoring organization: $\square$ AAFP $\square$ ABFM $\square$ STFM $\square$ ADFM
$\square$ AFMRD $\square$ NAPCRG $\square$ CFPC

ID number from label on your journal cover

OLD Information (Please print.)

\begin{tabular}{lc}
\hline Name \\
\hline Company (if applicable) \\
\hline Address (Street plus Apt or Ste) \\
\hline City \\
\hline Country \\
\hline Telephone \\
\hline E-Mail & Faxtal Code (9-digit ZIP for US) \\
\hline
\end{tabular}

NEW Information (Please print.)

\begin{tabular}{ll}
\hline Name \\
\hline Company (if applicable) \\
\hline Address (Street plus Apt or Ste) \\
\hline City & Postal Code (9-digit ZIP for US) \\
\hline Country & Fax \\
\hline Telephone & \\
\hline E-Mail &
\end{tabular}

